Antonio Burgos-Teruel'

Laia Bernet ${ }^{1}$

Jesús J. Gil-Tomás²

Jorge Jover-García ${ }^{3}$

Angela López'

Clara Osca ${ }^{4}$

\title{
Human Papillomavirus in the region of La Ribera-Valencia: Present and future
}

${ }^{1}$ Hospital Universitario de La Ribera. Ctra. De Corbera Km, 1, 46600, Alzira, Valencia, Spain.

${ }^{2}$ Hospital Universitario Casa de Salud. C/ Dr. Manuel Candela, 41, 46021, Valencia, Spain.

${ }^{3}$ Hospiten Roca. C/Buganvilla, 1, 35100, San Agustín, Gran Canaria, Spain.

${ }^{4}$ Universidad Politécnica de Valencia. Campus de Vera, S/N, Valencia, Spain.

\section{Article history}

Received: 11 November 2019; Revision Requested: 4 December 2019; Revision Received: 4 December 2019; Accepted: 16 December 2019; Published: 21 February 2020

\begin{abstract}
Introduction. Human Papillomavirus (HPV) is the main cause of cervical cancer. The etiology and effects derived from this infection are set by molecular techniques and cytological diagnosis, respectively. In the present study, data obtained by an opportunist screening of cervical cancer in La Ribera region are revised and related statistically.
\end{abstract}

Material and methods. Data considering different variables such as age, degree of lesion, HPV type detected and number of virus in coinfection were collected from 1,372 HPV positive cytology samples. HPV detection was carried out by means of three molecular techniques and the degree of lesion was analyzed by cytological diagnosis (Bethesda). In order to determine the relationship between different selected variables, several statistical analyses were performed.

Results. Only degree of lesion variable showed a direct relationship with the rest of variables, increasing with aging process, viral oncogenicity, presence of at least one high-risk virus and with the fact of being mono-infected. The probability of presenting a higher-level degree of lesion multiplied by 28.4 when high-risk HPV was detected in mono-infection.

Conclusions. HPV molecular detection is the most suitable technique to perform a cervix cancer primary screening for the management of women with negative cytological diagnose. The number of detected types is statistically related to the degree of lesion. The establishment of a properly regulated screening to identify HPV infection, and therefore, of cervical cancer risk, is essential.

Key-words: Human Papillomavirus, Cervical Cancer, Cancer Screening.

Correspondence:

Jesús J. Gil-Tomás

Hospital Universitario Casa de Salud. C/ Dr. Manuel Candela, 41, 46021, Valencia, Spain.

Phone: +34671121184.

E-mail: jesus.j.gil@uv.es

\section{Virus del papiloma humano en la comarca de La Ribera-Valencia: Presente y futuro}

\section{RESUMEN}

Introducción. El virus del papiloma humano (VPH) es la principal causa de cáncer cervical. La etiología y los efectos derivados de esta infección se establecen mediante técnicas moleculares y diagnóstico citológico, respectivamente. En el presente estudio, los datos obtenidos por un cribado oportunista de cáncer cervical en la comarca de La Ribera se revisaron y se relacionaron estadisticamente.

Material y métodos. Se recopilaron datos que incluyeron diferentes variables como la edad, el grado de lesión, el tipo de VPH detectado y el número de virus en coinfección de 1.372 citologías positivas para VPH. La detección del VPH se realizó mediante tres técnicas moleculares y el grado de lesión se analizó mediante diagnóstico citológico (Bethesda). Para determinar la relación entre las diferentes variables, se realizaron varios análisis estadísticos.

Resultados. Sólo la variable del grado de lesión mostró una relación directa con el resto de variables, aumentando con el proceso de envejecimiento, la oncogenicidad viral, la presencia de al menos un virus de alto riesgo y el hecho de estar mono-infectado. La probabilidad de presentar un mayor nivel de lesión se multiplicó por 28,4 cuando se detectó VPH de alto riesgo en la mono-infección.

Conclusiones. La detección molecular del VPH es la técnica más adecuada para realizar un cribado primario del cáncer de cuello uterino para el manejo de mujeres con diagnóstico citológico negativo. El número de tipos detectados está estadisticamente relacionado con el grado de lesión. El establecimiento de un cribado regulado adecuadamente para identificar la infección por VPH y, por lo tanto, del riesgo de cáncer cervical, es esencial.

Palabras clave: Virus del Papiloma Humano, Cáncer de Cuello Uterino, Detección Precoz del Cáncer. 


\section{INTRODUCTION}

Human Papillomavirus (HPV) belongs to the family $P a-$ povaviridae, subfamily Papillomaviridae. This virus is tissue-specific and infects both the cutaneous and mucosal epithelia. Its genome is divided into: an E region, of early expression encoding various structural proteins (E1-E7); an L region, of late expression, which encodes the capsid proteins ( $\mathrm{L} 1$ and $\mathrm{L} 2$ ); and a regulatory, non-coding region (RNC/LCR), located in the 5'-direction [1].

HPV types have been classified by their tissue tropism (mucous or cutaneous types), as well as their oncogenic potential [High (HR) and Low-Risk (LR) types]. The International Agency for Research on Cancer, defines 16 High-Risk HPV (HRHPV), associated with cancer in humans (types 16, 31, 33, 35, $52,58,73,18,39,45,59,68,5153,56,66)$ [2]. HPV-16 and HPV-18 types are responsible globally for $71 \%$ of cervical cancer cases [3].

Based on the antigenic and variable region $L 1$ genomic sequence, coding for the major protein of the capsid, about 200 types have been identified and characterized, defined as those that include more than 1\% difference in their nucleotide sequence. Phylogenetically, below in the scale of HPV types, lineages and sublineages are found, which differ by $1 \%$ and between $0.5-0.9 \%$ in their genomic sequence, respectively [2]

HPV infection is one of the most common sexually transmitted diseases in the world, as well as the main cause of cervical cancer, with a higher incidence in developing countries [4]. Most infections (70-90\%) are asymptomatic and resolve spontaneously in 1-2 years. The disease degree transmission, the asymptomatic infection development and the poor immunological response, are directly related to the virus success in its replicative process.

HR-HPV persistent infection, defined as the presence of an HPV specific type in clinical samples separated between 6 months and 1 year, is an indispensable condition for progression to infiltrating carcinoma [5]. Likewise, the sequence of events caused by HPV infection is gradual and detectable by cytology with Papanicolaou staining. The control of the disease is possible through primary (vaccination) and secondary (detection of HPV and cytological diagnosis) preventions, so global eradication of cervical cancer (the only type of cancer with this future forecast) is feasible, due to knowledge of the disease cause, development and treatment. This possible eradication can be achieved by raising the need to control the population infection through vaccination and well-established screenings. The population screening should be well structured, a target population should be identified, appropriate detection techniques should be chosen, and the time intervals should be defined according to age parameters.

As a primary control of the infection, a global vaccination strategy against HPV was launched ten years ago. Nowadays, the definitive results derived from this strategy are not available since the population to which it was directed, has just been incorporated into the population screening of individuals susceptible to prevention. In Spain, National Health Service recommendations for HPV secondary prevention have been published, consisting of a women population screening between 25 and 65 years of age [6].

Currently, cervical cancer screening is opportunistic and performed by cervico-vaginal cytology as a screening technique, with a variable periodicity of 1 to 3 or 5 years [7]. In its latest revision (https://bethesda.soc.wisc.edu), The Bethesda System substitutes the term Cervical Intraepithelial Neoplasia (CIN) for Squamous Intraepithelial Lesion (SIL), with two categories: Lowgrade (LSIL) and High-grade (HSIL) [8]. The WHO IARC (World Health Organization International Agency for Research on Cancer) reviewed in its monographs program the scientific evidence in relation to the HPV test as a primary screening technique and concluded [9], like other studies [10], that enough evidence in relation to viral detection tests was found, presenting at least the same results as Papanicolaou staining. According to controlled randomized trials, screening based on the detection of HPV DNA allows an early diagnosis of high-grade cervical neoplasia due to its high sensitivity. In addition, this approach may be more effective in the prevention of cervical cancer since, being a less specific technique than cytology, its negative predictive value is very high $[11,12]$.

HPV infections can be caused by a single type of virus (mono-infection) or by several at the same time (poly-infection). The effect of one or the other in the development of cervical cancer $[13,14]$, and the same prognosis of mono and poly-infections are controversial aspects.

The aims of this study were: to describe the distribution of the different HPV genotypes and their relationship with the different degrees of cervical pathology (cytology in liquid medium) in the female population selected by opportunistic screening criteria between 2012 and 2017 in Health Department 11 of the Valencian Community; to determine the relationship between the five variables studied for the total sample: cytological diagnosis, age, viral oncogenicity, detection of high-risk virus (HR-HPV) only and mono / poly-infection; and, to describe three molecular techniques comparing their results, among them and with the total samples.

\section{MATERIAL AND METHODS}

Cases and population. The series consisted of 3,541 cytology samples including a women population between 25 and 65 years, that underwent HPV detection and morphological study with Papanicolaou staining from liquid cytology (ThinPrep) classified according to Bethesda criteria. 1,372 samples (38.75\%) positive for at least one HPV type corresponded to the number of cases in the study. All cases belong to the opportunistic screening program for cervical cancer from 2012 to 2017 in the Department of Health 11 of Valencian Community that serves 46 municipalities with a total population in 2017 (www.ine.es) of 298,182 inhabitants (149,984 women and 148,288 men). 


\section{Definitions}

Case: positive cytology for HPV detection, regardless of whether it belongs to the same patient in clinical samples separated over time.

Degree of lesion: each of the morphological diagnostic categories (Bethesda classification).

Low-grade lesion: on the previous scale, from NORMAL to LSIL included.

High-grade lesion: on the aforementioned scale, from ASC-H (Atypical Squamous Cells, cannot exclude HSIL) to ADENOCARCINOMA.

Viral oncogenicity: ability of each type of HPV to favor progression towards adenocarcinoma [high-risk / low-risk HPV (HR-HPV / LR-HPV)].

Mono-infection: infection caused by a single type of HPV regardless of its viral oncogenicity.

Poly-infection: infection of more than one HPV type at the same time regardless of its viral oncogenicity.

HPV molecular detection. The detection of HPV DNA in the period was carried out by three different molecular methodologies based on the Polymerase Chain Reaction (PCR). In a first phase, a nested PCR was performed (technique 1) using as external primers MY109 and MY110 and, as internal GP5 + and GP6 +, that amplify a region of the L1 gene. The positive amplifications were sequenced for typing by the dideoxynucleotide triphosphate terminators method and subsequently, the editing with the software ChromasPro (Version 1.7.4 Technelysium Pty Ltd) and the comparison with the sequences of the NCBI database by means of BLAST (Basic Local Alignment Search Tool - NCBI - NIH), were carried out. The second phase, in addition to the previous one, included another Molecular Biology technique based on hybridization with probes (HPV Direct Flow CHIP Kit, MASTER DIAGNOSTIC (technique 2); this method can distinguish up to 36 HPV types. The negative results by this technique were processed by the nested PCR methodology described above due to its higher sensitivity. And in the third phase, the Anyplex II HPV 28 Detection Kit (Seegene) (technique 3) was used, which simultaneously detected, genotyped and semiquantified in two qPCR reactions, the 28 most prevalent high and low-risk HPV types, using the DPO system and melting curve analysis using TOCE technology.

Prior to the three techniques application, DNA extraction and quantification processes were implemented. The extraction was executed following the supplier's instructions using the Maxwe ${ }^{\circledR} 16$ FFPE Plus LEV DNA Purification Kit (Promega). DNA concentrations and purity were measured by spectrophotometry at 260 and $280 \mathrm{~nm}$ with Nanodrop2000. In techniques 1 and 2, the presence of amplification for subsequent sequencing or hybridization, respectively, was previously detected through an automatic capillary electrophoresis system [QiaXcel Advanced (QIAGEN)].

Statistical analysis. In an electronic database, the following variables were included for each patient: quantitative age; qualitative age in 4 groups (23-35 / 36-45 / 46-55 / > 56);

\begin{tabular}{ccccc}
\hline Table 1 & \multicolumn{2}{|l}{ Descriptive Age (qualitative) } \\
& & & & \\
$\mathrm{N}$ & Minimum & Maximum & Mean & Standard Deviation \\
\hline 1,372 & 25 & 65 & 37.433 & 9.207 \\
\hline
\end{tabular}

\section{Table $2 \quad$ Descriptive Qualitative Variables}

\begin{tabular}{|c|c|c|c|}
\hline Variables & Levels & N & $\%$ \\
\hline \multirow{5}{*}{ Age 4 groups } & $23-35$ & 661 & 48.2 \\
\hline & $36-45$ & 404 & 29.4 \\
\hline & $46-55$ & 254 & 18.5 \\
\hline & $>56$ & 53 & 3.9 \\
\hline & Total & 1,372 & 100 \\
\hline \multirow{3}{*}{ Age 2 groups } & $\leq 30$ & 388 & 28.3 \\
\hline & $>30$ & 984 & 71.7 \\
\hline & Total & 1,372 & 100 \\
\hline \multirow{7}{*}{$\begin{array}{l}\text { 'Papanicolaou' } \\
\text { result } \\
6 \text { categories }\end{array}$} & ADENOCARCINOMA & 2 & 0.1 \\
\hline & HSIL & 260 & 19.0 \\
\hline & ASC-H & 43 & 3.1 \\
\hline & LSIL & 570 & 41.5 \\
\hline & ASC-US & 311 & 22.7 \\
\hline & NORMAL/INFLAMMATION & 186 & 13.6 \\
\hline & Total & 1,372 & 100 \\
\hline \multirow{6}{*}{$\begin{array}{l}\text { 'Papanicolaou' } \\
\text { result } \\
5 \text { categories }\end{array}$} & ADENOCARCINOMA/HSIL & 262 & 19.1 \\
\hline & ASC-H & 43 & 3.1 \\
\hline & LSIL & 570 & 41.5 \\
\hline & ASC-US & 311 & 22.7 \\
\hline & NORMAL/INFLAMMATION & 186 & 13.6 \\
\hline & Total & 1,372 & 100 \\
\hline \multirow{4}{*}{ Technique } & Technique 1 & 174 & 12.7 \\
\hline & Technique 2 & 571 & 41.6 \\
\hline & Technique 3 & 627 & 45.7 \\
\hline & Total & 1,372 & 100 \\
\hline \multirow{3}{*}{ High/Low HPV risk } & Low-Risk (LR) & 193 & 14.1 \\
\hline & High-Risk (HR) & 1179 & 85.9 \\
\hline & Total & 1,372 & 100 \\
\hline \multirow{3}{*}{ Mono/poly HPV } & Mono & 782 & 57.0 \\
\hline & Poly & 590 & 43.0 \\
\hline & Total & 1,372 & 100 \\
\hline \multirow{2}{*}{ HR/LR Mono/Poly } & HR Mono-infected & 606 & 44.2 \\
\hline & HR Poly-infected & 573 & 41.8 \\
\hline \multirow{3}{*}{ HPV infected } & LR Mono-infected & 176 & 12.8 \\
\hline & LR Poly-infected & 17 & 1.2 \\
\hline & Total & 1,372 & 100 \\
\hline
\end{tabular}

HSIL: High-grade Squamous Intraepithelial Lesion; (LSIL): Low-grade Squamous Intraepithelial Lesion; ASC-H: Atypical Squamous Cells, cannot exclude HSIL; ACS-US: Atypical Squamous Cells of Undetermined Significance 
qualitative age in 2 groups $(\leq 30 />30)$; results of Papanicolaou staining in 6 groups (ADENOCARCINOMA / HSIL / ASC-H / LSIL / ASC-US (Atypical Squamous Cells of Undetermined Significance) / NORMAL or INFLAMMATION); results of Papanicolaou staining in 5 groups (ADENOCARCINOMA or HSIL / ASC-H / LSIL / ASC-US / NORMAL or INFLAMMATION); high / low-risk HPV: to create this variable, a cytology sample was considered to show an HPV high-risk result if at least one high-risk virus was presented and, a low-risk result, if any high-risk virus was not detected; mono / poly-infection: to create this variable, mono-infected was considered when only one virus was presented and, poly-infected, when more than one virus was detected, regardless of its oncogenicity; and, combination of high / low-risk HPV and mono / poly-infected results (high-risk HPV and poly-infected / high-risk HPV and mono-infected / low-risk HPV and poly-infected / low-risk HPV and mono-infected). In tables 1 and 2, the descriptive analysis of the variables is shown.

A descriptive analysis of the study variables was carried out; the qualitative variables were described by frequencies and percentages and, the quantitative variables, by dispersion measures (minimum, maximum, mean, standard deviation). A bivariate analysis was performed between the variables 'Papanicolaou staining', 'high/low-risk HPV' and 'mono/poly-infection' results with age (age variable was analyzed in a quantitative and qualitative way). In addition, a bivariate analysis was carried out in which the 'Papanicolaou staining' result was compared with the 'high/low-risk HPV' and 'mono/poly-infection' results. The qualitative variables were compared using the Chi square test, the quantitative variables with two levels, using the Student's T test and the quantitative variables with more than two levels, using the ANOVA and the post hoc Tukey tests to detect between which levels the differences were statistically significant. Odds Ratio (OR) and 95\% confidence intervals were calculated by adjusting simple logistic regression models. A confidence level of
0.05 was considered for the results interpretation. A virus type descriptive analysis was accomplished in each of the 'Papanicolaou staining' results categories; specifically, the number of patients belonging to each virus as well as to each virus combination found, were described. For the most frequent viruses (16, $18,31,33,42,51,53,56,66,45,58,59$ and 68 ) a dichotomous variable "The patient presents the virus (yes / no)" was created; this variable took the value 'yes' when the virus studied was detected in the cytology sample and takes the value 'no' when the virus studied was not. Subsequently, the dichotomous variables "The patient presents the virus (yes / no)" were compared with the 'Papanicolaou staining' results by the Chi square statistical test.

\section{RESULTS}

Distribution. The distribution of HPV types in this series is detailed in figure 1. In this study, the most frequent genotypes were $16,31,33,53,51$ (HR types) and 42 (LR type). 71.7\% of the total cases $(n=1,372)$ corresponded to 30 -years-old women or older. Infection induced by at least one HR-HPV was observed in $85.9 \%$ of the samples studied, whereas a $14.9 \%$ of the cases suffered from a LR-HPV infection. 57\% of cases belonged to mono-infection.

\section{Relationship between the different studied variables}

a) General situations. The diagnostic distribution of the 1,372 cases (positive HPV), according to Bethesda system, is shown in table 3. A multivariate study showed that only the variable "degree of lesion" (Papanicolaou test), of all the variables studied, presented a statistically significant direct relationship with each other. Thus, the degree of lesion increased with age, viral oncogenicity, the presence of at least one highrisk virus and with being mono-infected $(p<0.007, p<0.001$, $p<0.001, p<0.05$, respectively).

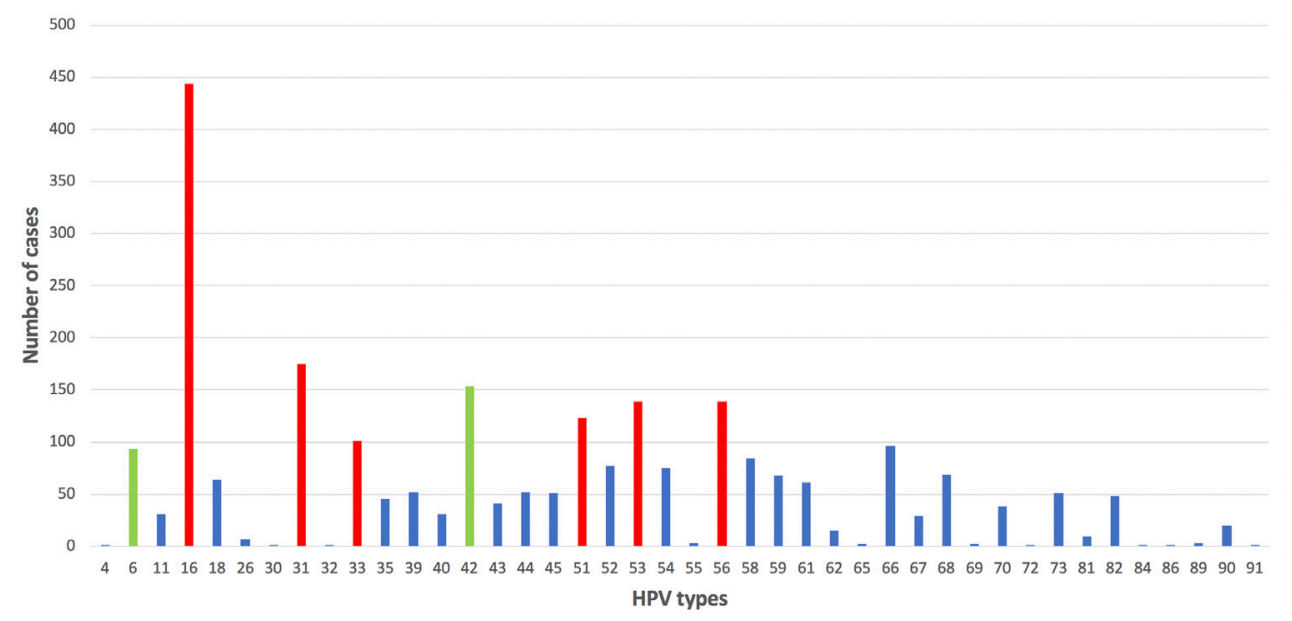

\begin{tabular}{l|l}
\hline Figure 1 & Distribution of HPV types.
\end{tabular}

Bar color red: most common HR-HPV types; bar color green: most common LR-HPV types; bar color blue: rest of HR/LR types. 


\begin{tabular}{c|cccccc}
\hline Table 3 & $\begin{array}{l}\text { Diagnostic distribution of the } 1,372 \text { cases } \\
\text { (positive HPV), according to Bethesda system }\end{array}$ \\
\hline Lesion & ADENOCARCINOMA & HSIL & ASC-H & LSIL & ASC-US & NORMAL \\
\hline$\%$ & 0.1 & 19 & 3.1 & 41.5 & 22.7 & 13.6 \\
\hline
\end{tabular}

HSIL: High-grade Squamous Intraepithelial Lesion; LSIL: Low-grade Squamous Intraepithelial Lesion; ASC-H: Atypical Squamous Cells, cannot exclude HSIL; ACS-US: Atypical Squamous Cells of Undetermined Significance.

\begin{tabular}{|c|c|c|c|c|c|}
\hline \multirow[t]{2}{*}{ Table 4} & \multicolumn{5}{|c|}{ Frequency distribution of lesions with the different variables } \\
\hline & Age (years) & $\%$ HR-HPV & $\begin{array}{c}\text { HR Mono } \\
\text { N (\%) }\end{array}$ & $\begin{array}{c}\text { HR Poly } \\
N(\%)\end{array}$ & Mono/poly-infection \\
\hline \multicolumn{2}{|l|}{ ADENOCARCINOMA } & 100 & & 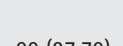 & \\
\hline HSIL & $>30$ & 98.8 & $100(01.07)$ & & \\
\hline ASC-H & & 88.4 & $16(37.21)$ & $22(51.16)$ & HR-poly \\
\hline LSIL & & 85.1 & $222(38.95)$ & $263(46.14)$ & HR-poly \\
\hline ASC-US & $\leq 30$ & 82.6 & $147(47.27)$ & $110(35.37)$ & HR-mono \\
\hline NORMAL & & 75.3 & $61(32.8)$ & 79 (42.47) & HR-poly \\
\hline
\end{tabular}

HSIL: High-grade Squamous Intraepithelial Lesion; LSIL: Low-grade Squamous Intraepithelial Lesion; ASC-H: Atypical Squamous Cells, cannot exclude HSIL; ACS-US: Atypical Squamous Cells of Undetermined Significance.

\begin{tabular}{l|l} 
Table 5 & $\begin{array}{l}\text { Distribution of HR-HPV types in mono/poly-infection } \\
\text { and the most frequent combinations, according to the } \\
\text { cytological diagnosis. }\end{array}$
\end{tabular}

\begin{tabular}{lccc}
\hline Cytological diagnosis & $\begin{array}{c}\text { Most frequent HPV } \\
\text { in mono-infection }\end{array}$ & $\begin{array}{c}\text { Most frequent HPV } \\
\text { in poly-infection }\end{array}$ & $\begin{array}{c}\text { Most frequent } \\
\text { combination }\end{array}$ \\
\hline HSIL & $16(61.4 \%)$ & $16(27.1 \%)$ & $16+33$ \\
LSIL & $16(25 \%)$ & $16(11.4 \%)$ & $16+56,16+33$ \\
ASC-US & $16(33 \%)$ & $31(19.6 \%)$ & none \\
NORMAL & $16(27.9 \%)$ & $53(7.7 \%)$ & none \\
\hline
\end{tabular}

HSIL: High-grade Squamous Intraepithelial Lesion; LSIL: Low-grade Squamous Intraepithelial Lesion; ACS-US: Atypical Squamous Cells of Undetermined Significance.

In this series, LSIL was more frequent in the group $\leq 30$ years, and HSIL in $>30$ years. High-grade lesions showed a higher frequency of HR-HPV. When the infection was solely due to HR-HPV, the risk of presenting a high-grade lesion with respect to NORMAL citology was 28.4 times higher. Thus, the risk of displaying a high-grade lesion if the HPV corresponded to high-risk was multiplied by 28.4. In addition, if poly-infection existed, the probability of obtaining a LSIL than NORMAL cytological result was multiplied by 2 (with data from technique 3) $(O R=2.16)(C l 1.36-3.44)(p<0.05)$.

The frequency distribution of lesions with different variables is shown in table 4.

b) Particular situations. Related to viral genotype, HPV 16 was associated more frequently with HSIL / LSIL $(p<0.001)$ than with the other Papanicolaou staining diagnoses; the risk of submitting a high-grade lesion was almost 10 times higher. In this study, the relationship between detecting an HPV 16 and the degree of lesion presented the following OR with respect to NORMAL cytology: $\mathrm{HSIL}(\mathrm{OR}=9.24)$, ASC-H (OR = 3.27), ASC-US $(O R=1.76)$ and $L S I L(O R=1.71) . H P V 42$ was linked with a higher frequency of ASCUS and NORMAL results $(p=0.001)$. If virus 42 was detected, the risk of ASC-H, ASC-US, HSIL and LSIL was less than being NORMAL $(O R=0.46, O R=0.86, O R=$ $0.24, \mathrm{OR}=0.96$, respectively). HPV 56 was more frequently associated with LSIL diagnosis than with the rest of diagnoses $(p=0.001)$. The risk of being LSIL versus being NORMAL was 1.89 times higher. HPV 66 was more frequently related to $L S I L$, being less frequent ASC-H and HSIL for this genotype $(p=0.004)$.

Table 5 shows the distribution according to the cytological diagnosis of HR-HPV types in mono and poly-infection, as well as the most frequent combinations.

Comparison amongst the three techniques. As explained previously, three techniques were employed for the detection of HPV: $45.7 \%$ was determined by technique $3,41.6 \%$ by technique 2 and $12.7 \%$ with technique 1 .

a) Relationship between the degree of lesion and infection with HR-HPV. In the total samples, the probability of presenting a highgrade lesion is multiplied by 28.4 times when the infection is caused by HR-HPV. It's multiplied by 18.75 times with technique 1 ; by 32.4 in technique 2 , and with technique 3 , HR-HPV was detected in 100\% of HSILs.

b) Relationship between the degree of lesion and mono or poly-infection, regardless of its oncogenic potential. With the total samples, significant differences between both variables occurred $(p=0.007)$; regarding to the degree of lesion, mono-infection and poly-infection were not comparable. From ASC-US to LSIL, the most frequent situation was poly-infection, while in high-grade lesions, mono-infection.

All the results obtained were mono-infections applying technique 1. Therefore, no relationship could be established; by applying technique 2, no significant differences existed relating both variables; and with technique 3 , significant differences between both variables happened $(p=0.00009)$, with the same considerations applied for the total of samples.

c) Mono or poly-infected with HR-HPV or LR-HPV only. In the total of samples, HR-HPV in mono or poly-infection was related to a value of $p<0.001$; this relation was not observed in the case of 
LR-HPV. These same results were obtained by applying technique 3 ( $p<0.001)$. In technique 1 , only mono-infections were found, so no relationship could be established; with technique 2, no statistical difference was found in the relationship of being HR-HPV / LR-HPV mono or poly-infected with the cytological study result.

\section{DISCUSSION}

The detection of HPV DNA in opportunistic screening cytology samples from Health Department 11 of the Valencian Community was carried out during a four-year period with three different PCR-based techniques. Data in this study, unlike others, were based on opportunistic and non-population screening. Thus, relative quantities to the total of the series were described and the terms "detection rates" or "frequencies" were used, against incidence or prevalence.

Of the total cases, three out of four (71.7\%) corresponded to women over 30 years of age; in this age group, at least one HR-HPV was detected in 9 out of 10. The high rate of HR-HPV $(85.9 \%)$ in this series is probably related to the easy and fast transmission of the virus itself and could suggest a colonization process rather than infection. In addition, only one in five cases progressed to lesion greater than HSIL. Thus, according to published data, a regression rate of $77.8 \%$ was observed [15]. Consistent with cytological diagnoses distribution (table 3), 13.6\% of them would not have been detected taking cytology as a primary screening test, being NORMAL, but detecting at least one HPV by PCR techniques. High-grade lesions were more frequent in women over 30 years of age than in younger women (88.4-100\% vs. 75.3-85.1\%; table 4), which is related to the logical temporal evolution of the lesions.

The probability of presenting a high-grade lesion was 28.4 times higher when a HR-HPV is detected in mono-infection. 2 out of 3 cytology samples with a high-grade lesion showed an HR-HPV in mono-infection. However, the variable 'poly-infection', even in HR-HPV types, was associated with low-grade lesions in this series. The influence of mono or poly-infection incidence on the development of cytological lesions is a controversial issue $[13,14]$. Data from this study suggest that poly-infection is a protective mechanism based on establishing a balance between the infectious virus types. Consequently, hegemony of any of them is not allowed and cytological morphology progresses to higher levels of LSIL.

As the degree of lesion evolves, the HPV number and types involved decrease. From ASC-US to LSIL, any type of HPV (HR or LR) was found; however, from LSIL onwards, higher frequency of high-risk types 16, 31, 51 and 53 were observed, being considered in our environment as the most oncogenic types. Also, the types 56 and 66, considered HR-HPV, prevailed especially in low-grade lesions which should rethink the definition of their oncogenicity. These types could produce highgrade lesions in selected patients due to immunosuppression or other causes as occurs with many other microorganisms considered non-pathogenic. However, high-grade lesions were not produced by these types in the study population.
In mono-infection, $1.2 \%$ of HSIL were associated with LR-HPV exclusively (6 and 11), as well as $11.6 \%$ of ASC-H $(42,54,67$ and 70$)$. Although this unexpected event could rethink the classification of these viruses as LR-HPV, these results could be attributed to the limitations of the techniques used, since most of these results ( 6 of 8 results) derived from technique 2, in which the correlation between sensitivity and specificity is not its main characteristic. The remaining two cases were detected with techniques 1 and 3 .

The high detection rate of HPV 16 (32.36\% overall) was independent of the extent of the lesion, appearing even in samples with NORMAL cytological diagnosis. Consequently, screening based only on cytology, infra diagnose this type of infections in which lesions progress slowly.

According to the techniques employed, technique 1 performed a sequence PCR, whereby sequencing of several types at the same time was not possible. Thus, all patients presented mono infection when using this technique; employing technique 2, statistically significant relationship between mono-poly infection and the Papanicolaou staining result ( $p=0.126$ ) was not discovered; and, with technique 3 , a statistically significant relationship between mono-poly infected and Papanicolaou staining was found ( $p<0.05)$; a poly infected patient presents 2,159 (1,136-3.44) times more risk of belonging to LSIL than NORMAL. Among the techniques used, technique 3 showed the best data due to its technology and the ability to detect different types of coinfectant viruses by analyzing melting curves. Regarding the present data, greater sensitivity and reproducibility of technique 3 versus 2 is shown. Technique 3 provides a good correlation between sensitivity and specificity, allowing HPV typing in all cases (data not shown).

The data and results provided are based on the opportunistic screening of HPV carried out in Department 11 of the Valencian Community and are representative of this geographical area. In addition, and as far as is known, this is the only descriptive and statistical study of opportunistic HPV screening in the Valencian Community.

At this time, the National Health Service of Spain has set the basis to establish a national system of cervical cancer population screening [6]. This system will allow a control of this pathology, the study of its evolution and possible disease eradication with the establishment of primary and secondary prevention measures.

The GARDASIL $9{ }^{\circledR}$ vaccine immunizes against types: 6, $11,16,18,31,33,45,52,58$. Although data on the vaccinated population are not yet available, this study concludes that HR-HPV 51 and 53, not included in the vaccine, appear with a frequency (8.97\% and $10.13 \%$ respectively) similar to some contained in this vaccine. This fact suggests a natural selection of these types compared to others, and therefore raises reconsideration of the types to be included in future vaccines.

The detection of HPV leads in the consideration of other adjuvant factors for better infection management; factors 
such as genotype, the presence of a poly or mono-infection or oncogenic capacity, together with the extent of the lesion, will influence the monitoring and treatment of the infection.

\section{FUNDING}

None to declare.

\section{CONFLICTS OF INTEREST}

The authors declare that they have no conflicts of interest.

\section{REFERENCES}

1. Mateos Lindemann $M L$, Pérez-Castro $S$, Pérez-Gracia MT, Rodríguez-Iglesias M. Sociedad Española de Enfermedades Infecciosas y Microbiología Clínica (SEIMC). Procedimientos en Microbiología Clínica. 57. Diagnóstico microbiológico de la infección por el virus del papiloma humano, 2016 [cited 01 October 2019]. Available from: https://seimc.org/contenidos/documentoscientificos/procedimientosmicrobiologia/seimc-procedimientomicrobiologia57.pdf

2. International Human Papillomavirus Reference Center. Human papillomavirus reference clones, 2019 [cited 16 October 2019]. Available from: https://www.hpvcenter.se/human_reference_ clones

3. de Sanjosé S et al. Human papillomavirus genotype attribution in invasive cervical cancer: a retrospective cross-sectional worldwide study. Lancet Oncol. 2010;11:1048-56. PMID: 20952254

4. Bray F, Ferlay J, Soerjomataram I, Siegel RL, Torre LA, Jemal A. Global cancer statistics 2018: GLOBOCAN estimates of incidence and mortality worldwide for 36 cancers in 185 countries. CA Cancer J Clin. 2018; 68:394-424. PMID: 30207593

5. Bosch FX, Lorincz A, Muñoz N, Meijer CJ, Shah KV. The causal relation between human papillomavirus and cervical cancer. J Clin Pathol, 2002;55:244-65. PMID: 11919208

6. Ministerio de Sanidad, Consumo y Bienestar Social. Sistema Nacional de Salud. Proyecto de orden por la que se modifican los anexos I, III y VI del Real Decreto 1030/2006, de 15 de septiembre, por el que se establece la cartera de servicios comunes del Sistema Nacional de Salud y el procedimiento para su actualización, 2018 [cited 05 September 2019]. Available from: https://www.mscbs. gob.es/normativa/audiencia/docs/OrdenModificacionCarteraSNS. pdf

7. Molina Barceló A, Moreno Salas J, Peiró Pérez R, Salas Trejo, D. European Partnership for Action Against Cancer (EPAAC). Análisis del cribado del cáncer en España desde una perspectiva de equidad, 2016 [cited 10 September 2019]. Available from: http://www. cribadocancer.es/images/archivos/CRIBADO_CANCER_EQUIDAD. pdf

8. Puig-Tintoré LM, Alba Menéndez A, Bosch $X$, Castellsagué $X$, Coll Capdevila $C_{1}$ Cortés Bordoy $X$ et al. La infección por papilomavirus. Documento de consenso de la SEGO, SEC y AEPCC. In: Puig-Tintoré LM, editor. Documentos de Consenso SEG0 2002. Madrid: Meditex-Sanex, 2003;p 41-104.
9. WHO International Agency for Research in Cancer (IARC) handbooks. Cervix Cancer Screening. IARC Handbooks of Cancer Prevention Volume 10, 2005 [cited 18 September 2019]. Available from: http://publications.iarc.fr/Book-And-Report-Series/larc-Handbooks-Of-Cancer-Prevention/Cervix-Cancer-Screening-2005

10. Ronco G, Dillner J, Elfström KM, Tunesi S, Snijders PJ, Arbyn M et al. Efficacy of HPV-based creening for prevention of invasive cervical cancer: follow-up of four European randomised controlled trials. Lancet. 2014;383:524-32. PMID: 24192252

11. de Sanjosé S. Cambios en el cribado del cáncer de cuello uterino. Aten Primaria. 2016;48:563-64. PMID: 27823635

12. Sankaranarayanan $R$, Nene BM, Shastri SS, Jayant $K$, Muwonge $R$, Budukh AM et al. HPV screening for cervical cancer in rural India. N Engl J Med. 2009;360:1385-94. PMID: 19339719

13. Salazar KL, Zhou HS, XU J, Peterson LE, Schwartz MR, Mody DR et al. Multiple Human Papilloma Virus Infections and Their Impact on the Development of High-Risk Cervical Lesions. Acta Cytol. 2015;59:391-8. PMID: 26674365

14. Depuydt CE, Thys S, Beert J, Jonckheere J, Salembier G, Bogers JJ. Linear viral load increase of a single HPV-type in women with multiple HPV infections predicts progression to cervical cancer. Int J Cancer. 2016;139:2021-32. PMID: 27339821

15. Alanen KW, Elit LM, Molinaro PA, McLachlin CM. Assessment of cytologic follow-up as the recommended management for patients with atypical squamous cells of undetermined significance or low grade squamous intraepithelial lesions. Cancer. 1998;84:5-10. PMID: 9500646 